\title{
KUALITAS KIMIA, FISIK DAN SENSORI KEFIR SUSU KAMBING YANG DISIMPAN PADA SUHU DAN LAMA PENYIMPANAN BERBEDA
}

\section{CHEMICAL, PHYSICAL AND SENSORY QUALITY OF GOAT MILK KEFIR DURING STORAGE UNDER DIFFERENT TEMPERATURES}

\author{
Triana Setyawardani*, Juni Sumarmono, Agustinus Hantoro Djoko Rahardjo, Mardiati \\ Sulistyowati, dan Kusuma Widayaka
}

Fakultas Peternakan, Universitas Jenderal Soedirman, Purwokerto, 53123

Submitted: 23 January 2017, Accepted: 12 July 2017

\section{INTISARI}

\begin{abstract}
Penelitian bertujuan untuk mempelajari kualitas kimia, fisik dan sensori kefir susu kambing yang disimpan pada temperatur dan lama simpan berbeda. Penelitian menggunakan metode eksperimental dengan rancangan acak lengkap pola faktorial. Faktor pertama adalah temperatur penyimpanan (-1 sampai $-5^{\circ} \mathrm{C}$; 1 sampai $5^{\circ} \mathrm{C}$ and 6 sampai $10^{\circ} \mathrm{C}$ ), faktor kedua adalah lama penyimpanan $(10 ; 20$ dan 30 hari). Hasil penelitian menunjukkan temperatur penyimpanan, lama penyimpanan dan interaksinya berpengaruh sangat nyata $(\mathrm{P}<0,01)$ terhadap kadar etanol, free fatty acids $(\mathrm{FFA})$; tetapi berpengaruh tidak nyata $(P>0,05)$ terhadap kadar protein, lemak dan abu kefir, sedangkan viskositas hanya dipengaruhi oleh temperatur penyimpanan $(\mathrm{P}<0,05)$. Untuk kadar $\mathrm{CO}_{2}$, tekstur dan rasa kefir dipengaruhi oleh lama penyimpanan. Kesimpulan penelitian adalah temperatur penyimpanan mempengaruhi kualitas kimia yaitu kadar etanol, FFA dan sifat fisik kefir yaitu viskositas sedangkan pengujian sensori kefir lebih dipengaruhi oleh lama penyimpanan.
\end{abstract}

(Kata kunci: Kefir, Penyimpanan, Sensori, Susu kambing, Temperatur)

\section{ABSTRACT}

The objective of this research was to investigate the chemical, physical and sensory properties of goat milk kefir during storage under different temperatures and storage time. The research used completely randomized factorial design. The first factor was temperature $\left(-1\right.$ to $-5^{\circ} \mathrm{C} ; 1$ to $5^{\circ} \mathrm{C}$ and 6 to $\left.10^{\circ} \mathrm{C}\right)$ and the second factor was storage time (10; 20 and 30 days) followed by Duncan test. Results showed that temperature, storage time and interaction of both highly significantly affected $(P<0.01)$ on the level of ethanol and free fatty acids (FFA), but did not affect $(P>0.05)$ on protein content, fat and ash, while $\mathrm{CO}_{2}$ level, texture and flavor of kefir were affected by storage time. Kefir viscosity was only affected by storage temperature $(P<0.05)$. It is concluded that storage temperature affected chemical properties such as ethanol, FFA and kefir viscosity, while kefir sensory properties were predominantly affected by storage.

(Key word: Goat milk, Kefir, Sensory, Storage, Temperature)

\section{Pendahuluan}

Kefir merupakan produk fermentasi dapat dibuat dari susu sapi, kambing, kerbau, unta dan kedelai dengan penambahan biji kefir sebagai starter yang terdiri dari sejumlah bakteri asam laktat (BAL) dan yeast yang terikat dalam matriks polisakarida (O'Brien et al., 2016). Kefir merupakan produk fermentasi yang unik karena pada proses fermentasi laktosa menghasilkan asam laktat dan etanol. Kefir dihasilkan dari aktivitas mikroorganisme dalam biji kefir yang mengandung BAL dan yeast (Guzel-Seydim et al., 2011; Satir dan Guzel-Seydim, 2016).

Susu kambing sebagai bahan baku kefir mempunyai keunggulan dibandingkan susu sapi, antara lain memiliki karakteristik sensori yang khas karena adanya aroma goaty yang bersumber dari asam lemak rantai pendek (Caponio et al., 2000; CaisSokolińska et al., 2015); mempunyai daya

\footnotetext{
${ }^{*}$ Korespondensi (corresponding author):

Telp. +62 85291003868

E-mail: trianaunsoed@gmail.com
} 
cerna lebih baik dibandingkan susu sapi (Haenlein, 2004; Park, 2007). Kefir berbahan dasar susu kambing Peranakan Ettawa (PE) memiliki potensi untuk dikembangkan sebagai pangan fungsional dalam produk kefir karena tidak hanya mengandung zat gizi makro, tetapi mampu menurunkan secara signifikan kadar laktosa susu yaitu dari 3,29 menjadi 2,45\% (Chen et al., 2005). Penurunan jumlah laktosa menunjukkan laktosa diubah oleh bakteri asam laktat yang termasuk dalam probiotik dalam biji kefir untuk menghasilkan sejumlah metabolit yang mempunyai peran fungsional.

Temperatur dan lama penyimpanan kefir merupakan faktor yang harus diperhatikan untuk mempertahankan kualitas kefir. Selama proses fermentasi, terjadi penurunan $\mathrm{pH}$ dan peningkatan jumlah asam laktat yang dihasilkan BAL, selanjutnya yeast akan menghasilkan etanol. Temperatur, lama penyimpanan, starter dan kondisi optimum fermentasi akan mempengaruhi sifat fisikokimia dan sensori kefir (Kakisu et al., 2011). Selama penyimpanan terjadi perubahan biokimia pada kefir, dan temperatur penyimpanan berperan penting terjadinya proses biokimia tersebut. Pada temperatur beku, mikroorganisme dalam kefir mengalami kerusakan, sedangkan pada temperatur dingin hanya terjadi perubahan aktivitas metabolisme menjadi lebih lambat dibandingkan pada temperatur ruang pada mikroorganisme kefir. Oleh karena itu tujuan penelitian ini adalah mempelajari kualitas kimia, fisik dan sensori kefir susu kambing yang disimpan pada temperatur dan lama simpan berbeda.

\section{Materi dan Metode}

\section{Produksi kefir susu kambing}

Sebanyak 54 liter susu kambing PE diambil dari peternak kambing Pegumas, Jawa Tengah dibawa dalam keadaan dingin. Susu kambing dipasteurisasi pada suhu $72^{\circ} \mathrm{C}$ selama 15 detik, dan didinginkan pada suhu kamar. Biji kefir merupakan koleksi Laboratorium Teknologi Hasil Ternak, Fakultas Peternakan, Universitas Jenderal Soedirman, yang diremajakan dengan menggunakan susu kambing setiap hari. Biji kefir dalam penelitian ini ditambahkan sebanyak $5 \%$ b/v, selanjutnya diinkubasi pada suhu ruang selama 24 jam. Tahapan selanjutnya adalah memisahkan biji kefir dengan susu kefir dengan menggunakan kain saring. Kefir disimpan pada temperatur dan lama penyimpanan sesuai dengan perlakuan.

\section{Komposisi kimia kefir}

Komposisi kimia kefir yaitu kadar air, protein, lemak dan abu diuji dengan metode standar (AOAC [Association of Official Analytical Chemists], 2006).

\section{Asam lemak bebas/free fatty acid (FFA)}

Pengujian FFA kefir dilakukan dengan titrasi dengan $\mathrm{NaOH} \mathrm{0,1} \mathrm{N} \mathrm{(Sudarmadji} \mathrm{et} \mathrm{al.,}$ 2007). Sampel kefir sebanyak $10 \mathrm{ml}$ dimasukkan ke dalam tabung erlenmeyer ditambahkan etanol $96 \%$ sebanyak $50 \mathrm{ml}$ dan indikator pp $2 \mathrm{ml}$. Kemudian dititrasi menggunakan $\mathrm{NaOH} \quad 0,1 \quad \mathrm{~N}$ (telah distandardisasi) sampai warna merah jambu dan warna tidak hilang selama 30 detik.

\section{Total etanol kefir}

Sebanyak $25 \mathrm{ml}$ sampel kefir ditambahkan $50 \mathrm{ml}$ aquades kemudian dimasukkan dalam labu destilasi. Destilasi dilakukan sampai volume penampung terisi $50 \mathrm{ml}$ (James, 1995). Dua tahapan yang dilakukan yaitu (1) pengukuran berat jenis sampel dan (2) pembacaan kadar etanol berdasarkan berat jenis sampel pada tabel spesific gravity ethanol ( $\% \mathrm{~b} / \mathrm{v})$.

\section{Kadar $\mathrm{CO}_{2}$ kefir.}

Penentuan kadar $\mathrm{CO}_{2}$ dilakukan dengan titrasi asam basa (AOAC [Association of Official Analytical Chemists], 2006).

\section{Viskositas}

Viskositas sampel kefir diukur dengan Brookfield viscometer dengan kecepatan 30 rpm (Temiz dan Kezer, 2015).

Pengujian sensori (Temiz dan Kezer, 2015)

Pengujian sensori kefir dilakukan oleh 25 panelis semi terlatih. Sampel kefir sebanyak $50 \mathrm{ml}$ disajikan dalam gelas kaca dan diberi kode secara acak dengan tiga digit angka. Jumlah sampel yang diuji sebanyak 12 sampel dan panelis menguji dengan metode skoring untuk atribut tekstur, rasa dan aroma.

\section{Rancangan percobaan}

Penelitian menggunakan rancangan acak lengkap pola faktorial $3 \times 3$. Faktor pertama adalah temperatur penyimpanan kefir yaitu : -1 sampai dengan $-5^{\circ} \mathrm{C}$; 1 sampai dengan $5^{\circ} \mathrm{C}$ dan 6 sampai dengan $10^{\circ} \mathrm{C}$ dan 
faktor kedua adalah lama penyimpanan yaitu: 10; 20 dan 30 hari. Masing-masing perlakuan diulang sebanyak 3 kali.

\section{Hasil dan Pembahasan}

\section{Kualitas kimia dan fisik kefir susu kambing}

Tabel 1 menunjukkan kadar protein kefir 3,30 $\pm 0,24$ sampai dengan $4,17 \pm 0,54 \%$, dimana temperatur, lama penyimpanan dan interaksinya berpengaruh tidak nyata $(P>0,05)$ terhadap kadar protein kefir. Kefir yang disimpan pada temperatur dan lama penyimpanan sampai 30 hari, mempunyai kadar protein yang sama. Selama penyimpanan tidak terjadi peningkatan kadar protein kefir. Hal ini disebabkan biomassa hasil dari mikroba kefir dihasilkan secara optimal saat fermentasi 24 jam dan tidak terjadi penambahan jumlah protein pada kefir selama penyimpanan, demikian juga dengan lemak dan kadar abu. Kadar protein tersebut sejalan dengan hasil penelitian Magalhães et al. (2011a) pada kefir dengan lama fermentasi 24 jam yaitu $3,91 \pm 0,02 \%$ dan Otles and Cadingi (2003) yaitu 3,3\% tetapi lebih rendah dari penelitian Suriasih et al. (2012) yaitu $5,5 \%$. Perbedaan tersebut dipengaruhi oleh lama fermentasi yang digunakan berbeda yaitu 24, 48 dan 72 jam yang akan mempengaruhi komponen kimiawi kefir. Selain faktor lama fermentasi, jenis susu dan komposisi biji kefir juga mempengaruhi komposisi kimiawi kefir (Sady et al., 2007). Perbedaan tersebut dipengaruhi oleh teknologi yang digunakan dalam menghasilkan kefir dan akan mempengaruhi komponen kimiawi kefir.

Temperatur, lama penyimpanan dan interaksinya berpengaruh tidak nyata $(P>0,05)$ terhadap kadar lemak kefir. Semakin tinggi temperatur penyimpanan dan semakin lama penyimpanan tidak menyebabkan terjadinya peningkatan kadar lemak kefir. Kadar lemak mempunyai rerata 4,64 $0,78 \%$. Kadar lemak yang dihasilkan lebih tinggi dari penelitian (Chen et al., 2005) yaitu $3,30 \pm 0,02 \%$. Mikroorganisme dalam biji kefir sangat komplek terdiri dari sejumlah bakteri asam laktat yang mampu menghasilkan enzim lipase dan protease dan sejumlah yeast yang terikat dalam matriks polisakarida yang akan dilepaskan selama proses fermentasi dan selama kefir disimpan, dimungkinkan selama penyimpanan tidak terjadi pelepasan lipase dari bakteri asam laktat penghasil lipase tersebut sehingga kadar lemak kefir relatif tetap selama penyimpanan tidak terjadi pelepasan lipase, protease dan laktat dari mikroorganisme yang terdapat dalam biji kefir sehingga kadar lemaknya tetap. Kwak et al. (1996) menjelaskan terjadinya penurunan kadar lemak selama penyimpanan dikarenakan terjadinya pelepasan lipase dari mikroorganisme dalam biji kefir. Selama penyimpanan kadar lemak mengalami perubahan kecil sehingga menghasilkan kadar lemak kefir yang relatif sama, hasil ini sejalan dengan peneliti sebelumnya oleh Irigoyen et al. (2005), tetapi lebih tinggi dibandingkan penelitian oleh (Chen et al., 2009; Magalhães et al., 2011b), dimana suhu penyimpanan dan lama penyimpanan tidak memberikan pengaruh terhadap kadar lemak yang dihasilkan pada kefir susu kambing.

Temperatur penyimpanan, lama penyimpanan dan interaksinya berpengaruh tidak nyata $(P>0,05)$ terhadap kadar abu kefir

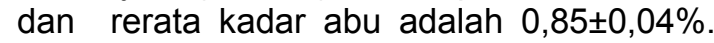
Abu merupakan bagian dari total padatan, termasuk di dalamnya kadar lemak dan protein selama penyimpanan memiliki variasi jumlah yang relatif kecil sehingga tidak menyebabkan perbedaan, dimana biomassa kefir terdiri dari protein, lemak dan abu yang relatif sama dan tidak mengalami perubahan selama penyimpanan. Sarkar (2007) menyatakan bahwa kefir mengandung abu sebesar 0,7\%, sedangkan (Kök-Taş et al., 2013) melaporkan bahwa kefir mengandung abu dengan kisaran 0,55 sampai 0,66\%.

Temperatur penyimpanan berpengaruh tidak nyata $(P>0,05)$, lama penyimpanan berpengaruh sangat nyata $(P<0,01)$ dan interaksinya berpengaruh sangat nyata $(P<0,01)$ terhadap kadar $\mathrm{CO}_{2}$ kefir dengan rerata $\quad 0,915 \pm 0,10 \%$. Karbondioksida dihasilkan oleh yeast yang terdapat dalam biji kefir selama proses fermentasi kefir. Bakteri asam laktat heterofermentatif dalam biji kefir selain menghasilkan metabolit berupa asam laktat, juga menghasilkan asetaldehid, diasetil serta asam aseton untuk menghasilkan flavor dan aroma khas kefir Karbondioksida diproduksi oleh starter berupa biji kefir yang terdiri dari asam laktat dan yeast yang berperan dalam menghasilkan asam laktat, karbondioksida, etanol, asetaldehid dan diasetil serta asam aseton untuk menghasilkan flavor dan aroma khas kefir (Beshkova et al., 2003). Kadar $\mathrm{CO}_{2}$ yang 
tinggi akan menguntungkan karena $\mathrm{CO}_{2}$ berperan penting dalam pembentukan flavor dan aroma kefir. Semakin lama penyimpanan sampai dengan 20 hari, terjadi peningkatan kadar $\mathrm{CO}_{2}$ kefir setelah itu terjadi penurunan.

Semakin tinggi temperatur dan semakin lama penyimpanan sampai dengan 30 hari meningkatkan kadar etanol kefir. Temperatur, lama penyimpanan dan interaksinya berpengaruh sangat nyata $(P<0,01)$ terhadap etanol kefir. Semakin tinggi temperatur penyimpanan, maka kadar etanol kefir semakin meningkat, hal ini disebabkan etanol akan dihasilkan oleh yeast sebagai hasil metabolitnya pada suhu yang lebih tinggi dan setelah 45 jam fermentasi pada suhu $25^{\circ} \mathrm{C}$ dan semakin lama penyimpanan kadar etanol kefir semakin meningkat. Selama proses fermentasi, BAL akan mengubah laktosa untuk menghasilkan asam laktat dan akan menurunkan $\mathrm{pH}$. Proses selanjutnya yeast akan melakukan aktivitasnya, untuk menghasilkan etanol sebagai hasil metabolitnya. Besarnya etanol yang akan dihasilkan oleh yeast dipengaruhi oleh jumlah atau konsentrasi biji kefir dan lama waktu fermentasi (Simova et al., 2002a; Farnworth dan Mainville, 2003). Selanjutnya diikuti oleh yeast sehingga besarnya etanol yang dihasilkan oleh yeast dipengaruhi oleh jumlah atau konsentrasi biji kefir dan lama waktu fermentasi. Laktosa akan diubah setelah 24 jam fermentasi menjadi galaktosa dan glukosa oleh beberapa strain Streptococcus dan Kluyveromyces (Magalhães et al., 2011a) Bakteri asam laktat dalam kefir grain mempunyai kisaran $83-90 \%$ dan proporsi spesies homofermentatif dan yeast sekitar 10 sampai $17 \%$.

Hasil penelitian menunjukkan rerata kadar etanol kefir adalah 0,530 $\pm 0,05$ sampai $1,39 \pm 0,05 \%$. Hasil analisis statistik memperlihatkan bahwa temperatur, lama penyimpanan dan interaksinya memberikan pengaruh sangat nyata $(P<0,01)$ terhadap kadar etanol kefir susu kambing. Kadar etanol yang dihasilkan selama 10 hari masa penyimpanan kefir mempunyai rerata $0,58 \%$ dan lebih rendah dibandingkan penelitian (Usmiati dan Sudono, 2004) yaitu $0,62 \%$. Semakin lama penyimpanan sampai dengan 30 hari terjadi kenaikan kadar etanol kefir. Rerata kadar etanol terendah pada suhu penyimpanan beku ( -1 sampai $\left.-5^{\circ} \mathrm{C}\right)$, yaitu sebesar $0,718 \%$ kondisi ini dimungkinkan terjadi perubahan komposisi starter pada saat kefir disimpan beku sehingga pada suhu beku proses fermentasi berjalan sangat lambat dan etanol yang dihasilkan menjadi lebih rendah dibandingkan penyimpanan suhu di atasnya.

Etanol dan $\mathrm{CO}_{2}$ dihasilkan dari yeast, laktosa dan sumber gula lain yang digunakan untuk menghasilkan etanol selama proses fermentasi kefir. Beberapa jenis yeast yang menghasilkan etanol dalam kefir seperti Kluyveromyces lactis, Kluyveromyces marxianus, Kluyveromyces fragilis, Torula kefir, dan Saccharomyces (Kwak et al., 1996).

Selama penyimpanan proses metabolisme dalam kefir tetap berjalan sampai pada 30 hari masa penyimpanan, yeast lebih mendominasi dibandingkan BAL sehingga kadar etanol yang dihasilkan semakin banyak. Magalhães et al. (2011a) menjelaskan Saccharomyces cerevisiae berperan dalam menghasilkan etanol pada kefir di samping itu beberapa strain Lactobacillus juga mempunyai kemampuan menghasilkan etanol karena memiliki aktivitas etanol dehidrogenase yang merupakan enzim yang berperan mengubah asetaldehid menjadi etanol.

Etanol pada kefir dihasilkan dari yeast yang ada pada biji kefir. Beberapa jenis yeast yang menghasilkan etanol dalam kefir seperti Kluyveromyces lactis, Kluyveromyces marxianus, Kluyveromyces fragilis, Torula kefir, dan Saccharomyces (Kwak et al., 1996). Kadar etanol kefir sangat bervariasi yaitu 0,01 sampai $1,00 \%$ tergantung pada kultur yang digunakan, lama fermentasi, suhu dan suhu penyimpanan jenis penyimpan. Meningkatnya kadar etanol pada suhu penyimpanan $1-5^{\circ} \mathrm{C}$ pada fermentasi diawali dengan aktivitas $B A L$ yang bekerja sampai diperoleh $\mathrm{pH}$ yang sesuai, kemudian yeast akan bekerja untuk menghasilkan etanol dan $\mathrm{CO}_{2}$. Pada suhu rendah kadar etanol yang dihasilkan lebih kecil dibandingkan kefir yang disimpan pada suhu ruang $(0,46$ vs $0,66 \%)$. Pada kefir terjadinya fermentasi asam laktat berakhir dengan menurunnya nilai $\mathrm{pH}$, dan khamir/yeast masih melakukan aktivitasnya dengan cara menggunakan laktosa dan gula selama penyimpanan pada suhu yang sesuai (Usmiati dan Sudono, 2004).

Tabel 1 menunjukkan kadar FFA kefir mempunyai kisaran 5,11 $\pm 0,56$ sampai dengan 8,59 $\pm 0,37 \%$. Temperatur, lama penyimpanan dan interaksinya berpengaruh sangat nyata $(P<0,01)$ terhadap kadar FFA kefir, dengan rerata $6,58 \pm 1,20 \%$. Free fatty acid bertambah selama terjadi perubahan 


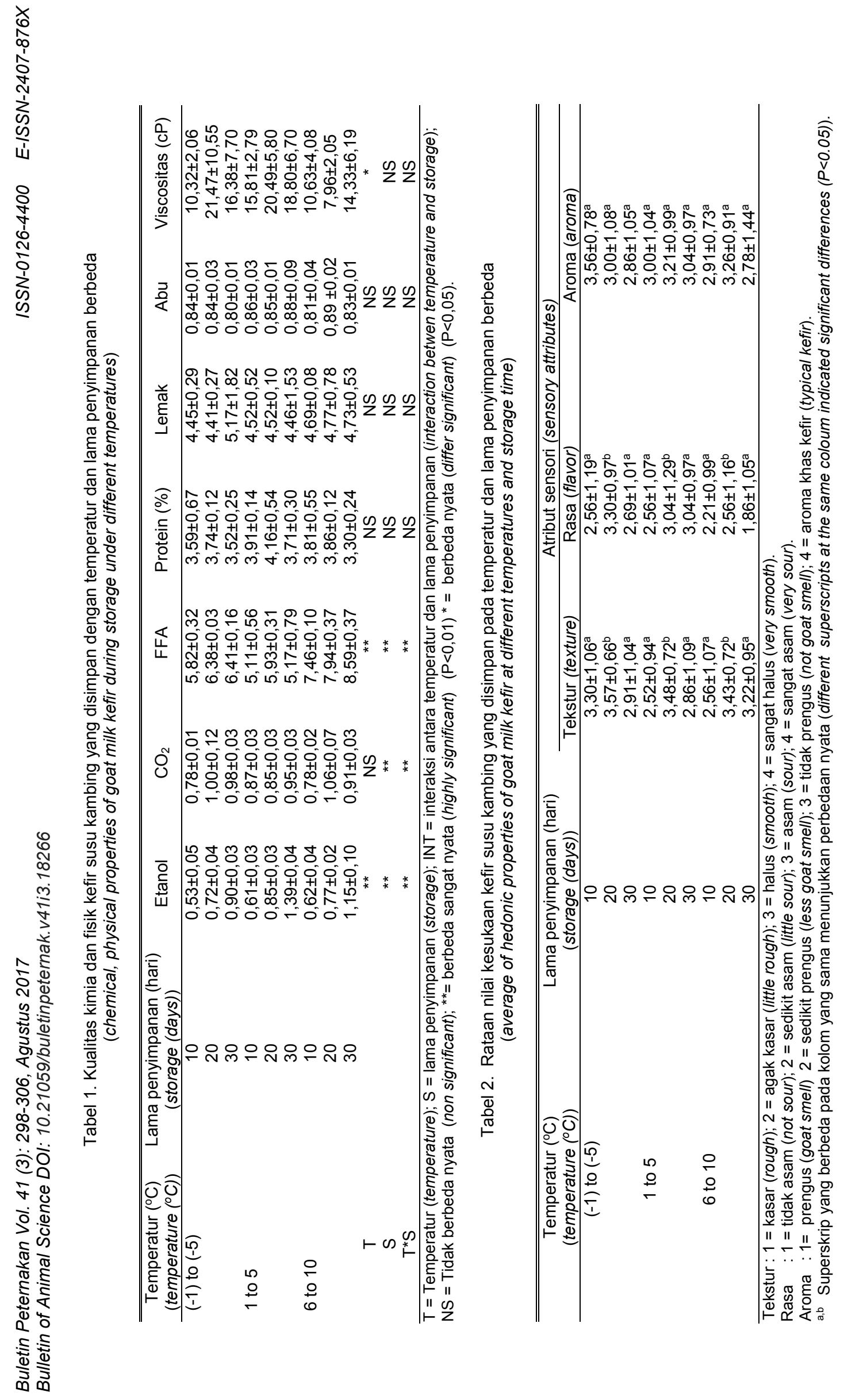


laktosa seperti deaminasi oksidatif, transaminasi dan dekarboksilasi asam amino (Ott et al., 1997). Perubahan kadar FFA selama penyimpanan dipengaruhi secara langsung oleh jenis kultur dengan jumlah FFA tertinggi diperoleh pada hari terakhir penyimpanan. Jumlah FFA akan mempengaruhi kualitas organoleptik dan nutrisi dari produk susu. Terjadi peningkatan kadar FFA dalam kefir selama penyimpanan dan bertambahnya temperatur penyimpanan (Reguła, 2007) menambahkan peningkatan jumlah FFA juga terjadi dimungkinkan karena tingginya kadar asam asetat yang mendominasi susu. Kadar asam asetat dalam produk fermentasi dikaitkan dengan metabolisme gula dan asam amino dibandingkan dengan hidrolisis lemak. (Reguła, 2007) menyatakan bahwa asam lemak bebas yang terdapat dalam susu merupakan substrat yang baik untuk enzim yang dihasilkan oleh beberapa campuran bakteri dalam biji kefir selama fermentasi. Perubahan hidrolisis yang kompleks dalam susu yang disebabkan oleh adanya kultur campuran merupakan sumber asam asetat.

Tabel 1 menunjukkan penyimpanan berpengaruh nyata $(P<0,05)$ terhadap viskositas kefir sedangkan lama penyimpanan dan interaksinya berpengaruh tidak nyata $(P>0,05)$ dengan rerata $15,14 \pm 6,74 c P$. Semakin tinggi temperatur penyimpanan viskositas kefir semakin menurun. Viskositas kefir tetap selama penyimpanan, dengan viskositas tertinggi $21,47 \pm 10,55 \mathrm{cPa}$ pada penyimpanan beku ((-1) to (-5)). Faktor-faktor yang mempengaruhi viskositas pada curd kefir dihasilkan oleh BAL dalam memfermentasi susu menyebabkan viskositas meningkat. Selain itu viskositas kefir juga dipengaruhi oleh pertumbuhan strater yang digunakan, jika mengandung bakteri yang menghasilkan eksopolisakarida dengan berat molekul besar yang akan menghasilkan susu fermentasi dengan viskositas tinggi.

\section{Sifat sensori kefir}

Hasil pengujian (Tabel 2) menunjukkan lama penyimpanan berpengaruh sangat nyata $(P<0,01)$ terhadap tekstur dan rasa tetapi berpengaruh tidak nyata $(P>0,05)$ terhadap aroma kefir. Temperatur penyimpanan berpengaruh tidak nyata $(P>0,05)$ terhadap tekstur, rasa dan aroma kefir susu kambing. Tekstur kefir mempunyai nilai sensori dengan skor tertinggi pada kefir yang disimpan selama 20 hari yaitu 3,48 dengan kriteria tekstur halus.

Tekstur hasil produk fermentasi dipengaruhi oleh viskositas, yang berhubungan dengan produk eksopolisakarida yang dihasilkan oleh kultur starter. Beberapa strain Streptococcus thermophyllus mampu menghasilkan polisakarida dengan berat molekul tinggi (Kakisu et al., 2011). Beberapa peneliti menyatakan bahwa tekstur produk fermentasi dipengaruhi oleh lama penyimpanan yang dinilai secara sensori.

Viskositas juga dipengaruhi oleh perubahan keasamaan yang berperan nyata dalam viskositas yogurt dan sensitifitas terjadinya sineresis dan akan mempengaruhi hasil penilaian organoleptik (Rohm dan Kovac, 1994; Barrantes et al., 1996). Semakin banyak mikroflora dari biji kefir yang terdiri dari strain Sterptococus thermophyllus maka tekstur kefir yang dihasilkan semakin halus karena menghasilkan polisakarida dengan BM yang tinggi.

Penilaian terhadap atribut rasa kefir mempunyai rerata skor tertinggi pada penyimpanan 20 hari yaitu dengan skor 2.97 , dengan kriteria rasa asam dan yeasty. Ketajaman rasa asam dan yeasty menghasilkan sensasi prickly yang dihasilkan oleh adanya karbondioksida oleh yeast yang menghasilkan rasa khas kefir (Irigoyen et al., 2005). Kefir yang disimpan selama 30 hari dengan suhu berbeda tidak menghasilkan perbedaan aroma. Panelis menilai aroma dengan skor rerata adalah 3,07 $\pm 1,02$ dengan kriteria kefir yang berbau khas dan tidak prengus. Beberapa faktor yang mempengaruhi pembentukan aroma khas kefir, terjadi fermentasi asam dan etanol (Irigoyen et al., 2003).

Mikroflora yang beragam pada kefir grains juga berperan sebagai komponen rasa yang menghasilkan karakteristik sensori. Tingkat lipolitik dan aktivitas proteolitik pada bakteri asam laktat selama penyimpanan seperti proses terjadinya pembebasan peptida dan asam amino tidak hanya menghasilkan perubahan yang signifikan terhadap rasa dan bau tetapi juga perubahan struktur dan konsistensi kefir (Irigoyen et al., 2005). Rasa asam yeasty terjadi selama proses fermentasi, BAL akan mengubah laktosa untuk menghasilkan asam laktat dan menurunkan $\mathrm{pH}$ selanjutnya diikuti oleh yeast (Simova et al., 2002b). Selain itu perubahan rasa asam dan bau dihubungkan dengan 
terjadinya perubahan kualitas sensori, yang dipengaruhi oleh jenis kultur dan lama penyimpanan (Rohm dan Kovac, 1994; Barrantes et al., 1996).

Produk utama fermentasi kefir adalah asam laktat, asetaldehid, diasetil, aseton, etanol, karbondioksida dan asam lemak bebas seperti asetat, propionat, butirat, hekanoik (Alonso dan Fraga, 2001; Beshkova et al., 2003) yang dimungkinkan menutup aroma goaty pada kefir yang dihasilkan. Selain itu aroma khas susu sebagai bahan baku bersumber dari asam lemak susu, termasuk asam lemak volatil yang mempengaruhi bau khas adalah butirat, kaproat, kaprilat, kaprat dan laurat. Asam lemak yang mudah larut yang berperan antara lain asam butirat, kaprilat dan kaprat. Proses lipolisis yang terjadi selama fermentasi susu diduga mempengaruhi citarasa produk akhir. Jenis kultur yang digunakan juga akan mempengaruhi rasa dan aroma yang tetap tidak mengalami perubahan selama penyimpanan. Kefir yang disimpan pada suhu lebih rendah mempunyai skor aroma dan rasa lebih tinggi dibandingkan yang disimpan pada suhu lebih tinggi (CaisSokolińska et al., 2008). Karbondioksida diproduksi oleh starter berupa biji kefir yang terdiri dari asam laktat dan yeast yang berperan dalam menghasilkan asam laktat, karbondioksida, etanol, asetaldehid dan diasetil serta asam aseton untuk menghasilkan flavor dan aroma khas kefir (Beshkova et al., 2003). Etanol dan $\mathrm{CO}_{2}$ berperan penting dalam pembentukan flavor dan aroma kefir. Peranan $K$ marxianus var lactis yang terdapat dalam biji kefir memetabolisme laktosa melalui fermentasi etanol dan akan membentuk aroma dan flavor khas yeast. Karbondioksida berasal dari fermentasi etanol dan berasal dari bakteri heterofermentatif yang menjadikan kefir mempunyai karakteristik mendesis yang dihasilkan selama fermentasi berlangsung (Lee et al., 2010).

\section{Kesimpulan}

Temperatur penyimpanan mempengaruhi kualitas kimia etanol, FFA dan viskositas kefir sedangkan pengujian sensori kefir lebih dipengaruhi oleh lama penyimpanan.

\section{Ucapan Terima Kasih}

Ucapan terima kasih kepada Rektor Universitas Jenderal Soedirman atas dana BLU penelitian Skim Riset Institusional (RISIN) tahun 2014.

\section{Daftar Pustaka}

Alonso, L. and M. Fraga. 2001. Simple and rapid analysis for quantitation of the most important volatile flavor compounds in yogurt by headspace gas chromatography-mass spectrometry. J. Chromatogr. Sci. 39: 297-300.

AOAC [Association of Official Analytical Chemists]. 2006. Official Method of Analysis. $15^{\text {th }}$ edn. Association of Official Analytical Chemists Inc., Virginia USA.

Barrantes, E., A. Tamime, A. Sword, D. Muir, and M. Kalab. 1996. The manufacture of set-type natural yoghurt containing different oils-2: Rheological properties and microstructure. Int. Dairy. J. 6: 827837.

Beshkova, D., E. Simova, G. Frengova, Z. Simov, and Z. P. Dimitrov. 2003. Production of volatile aroma compounds by kefir starter cultures. Int. Dairy. J. 13: 529-535.

Cais-Sokolińska, D., R. Danków, and J. Pikul. 2008. Physicochemical and sensory characteristics of sheep kefir during storage. Acta. Sci. Pol. 7: 63-73.

Cais-Sokolińska, D., J. Wójtowski, J. Pikul, R. Danków, M. Majcher, J. Teichert, and E. Bagnicka. 2015. Formation of volatile compounds in kefir made of goat and sheep milk with high polyunsaturated fatty acid content. J. Dairy Sci. 98: 6692-6705.

Caponio, F., T. Gomes, V. Alloggio, and A. Pasqualone. 2000. An effort to improve the organoleptic properties of a soft cheesefrom rustic goat milk. Eur. Food Res. Technol. 211: 305-309.

Chen, M. J., J. R. Liu, C. W. Lin, and Y. T. Yeh. 2005. Study of the microbial and chemical properties of goat milk kefir produced by inoculation with Taiwanese kefir grains. Asian-Aust. J. Anim. Sci. 18: 711-715. 
Chen, T. H., S. Y. Wang, K. N. Chen, J. R. Liu, and M. J. Chen. 2009. Microbiological and chemical properties of kefir manufactured by entrapped microorganisms isolated from kefir grains. J. Dairy Sci. 92: 3002-3013.

Farnworth, E. R. and I. Mainville. 2003. Kefir: a fermented milk product. In: Handbook of Fermented Functional Foods. E. R. Farnworth (Ed.). Tailor \& Francis Grup, Boca raton, FL. Pp 77-112.

Guzel-Seydim, Z. B., T. Kok-Tas, A. K. Greene, and A. C. Seydim. 2011. Review: Functional Properties of Kefir. Food. Sci. Nut. 51: 261-268.

Haenlein, G. 2004. Goat milk in human nutrition. Small. Rum. Res. 51: 155163.

Irigoyen, A., I. Arana, M. Castiella, P. Torre, and F. Ibanez. 2005. Microbiological, physicochemical, and sensory characteristics of kefir during storage. Food. Chem. 90: 613-620.

Irigoyen, A., M. Ortigosa, P. Torre, and F. Ibanez. 2003. Influence of different technological parameters in the evolution of $\mathrm{pH}$ during fermentation of kefir. Milchwissenschaft 58: 631-633.

James, C. 1995. Analytical Chemistry of Food. $1^{\text {st }}$ edn. Blackle Academic \& Profesional, UK.

Kakisu, E., A. Irigoyen, P. Torre, G. L. De Antoni, and A. G. Abraham. 2011. Physicochemical, microbiological and sensory profiles of fermented milk containing probiotic strains isolated from kefir. J. Dairy Res. 78: 456-463.

Kök-Taş, T., A. C. Seydim, B. Özer, and Z. B. Guzel-Seydim. 2013. Effects of different fermentation parameters on quality characteristics of kefir. J. Dairy Sci. 96: 780-789.

Kwak, H. S., S. K. Park, and D. S. Kim. 1996. Biostabilization of Kefir with a Nonlactose-Fermenting Yeast. J. Dairy Sci. 79: 937-942.

Lee, J. I., K. Y. Song, J. W. Chon, J. Y. Hyeon, and K. H. Seo. 2010. Physicochemical properties of kefir as dietary supplementary for curing the diabetic mouse. Korean J. Food Nutr. 23: 462469.

Magalhães, K. T., G. Dragone, G. V. de Melo Pereira, J. M. Oliveira, L. Domingues, J. A. Teixeira, J. B. A. e Silva, and R. F. Schwan. 2011a. Comparative study of the biochemical changes and volatile compound formations during the production of novel whey-based kefir beverages and traditional milk kefir. Food. Chem. 126: 249-253.

Magalhães, K. T., G. V. d. M. Pereira, C. R. Campos, G. Dragone, and R. F. Schwan. 2011b. Brazilian kefir: structure, microbial communities and chemical composition. Brazilian J. Microbiology 42: 693-702.

O'Brien, K. V., K. J. Aryana, W. Prinyawiwatkul, K. M. C. Ordonez, and C. A. Boeneke. 2016. Short communication: The effects of frozen storage on the survival of probiotic microorganisms found in traditionally and commercially manufactured kefir. J. Dairy. Sci. 99: 7043-7048.

Otles, S. and O. Cadingi. 2003. Kefir: A probiotic dairy-composition, nutritional and therapeutic aspects. Pakistan $\mathrm{J}$. Nutr. 2: 54-59.

Ott, A., L. B. Fay, and A. Chaintreau. 1997. Determination and origin of the aroma impact compounds of yogurt flavor. Agric. Food. Chem. 45: 850-858.

Park, Y. W. 2007. Rheological characteristics of goat and sheep milk. Small Rumin. Res. 68: 73-87.

Reguła, A. 2007. Free fatty acid profiles of fermented beverages made from ewe's milk. Le Lait 87: 71-77.

Rohm, H. and A. Kovac. 1994. Effects of starter cultures on linear viscoelastic and physical properties of yogurt gels. J. Texture. Stud. 25: 311-329.

Sady, M., J. Domagała, T. Grega, and D. Najgebauer-Lejko. 2007. Sensory and physico-chemical properties of commercially available kefir. Biotechnology in Animal Husbandry 23: 199-206.

Sarkar, S. 2007. Potential of kefir as a dietetic beverage-a review. British Food J. 109: 280-290.

Satir, G. and Z. B. Guzel-Seydim. 2016. How kefir fermentation can affect product composition? Small Rumin. Res. 134: 1-7.

Simova, E., D. Beshkova, A. Angelov, T. Hristozova, G. Frengova, and Z. Spasov. 2002a. Lactic acid bacteria and yeasts in kefir grains and kefir made from them. J. Inorg. 28: 1-6.

Simova, E., D. Beshkova, A. Angelov, T. Hristozova, G. Frengova, and Z. Spasov. 2002b. Lactic acid bacteria 
and yeasts in kefir grains and kefir made from them. J. Industrial Microbiology and Biotechnology 28: 16.

Sudarmadji, S., Haryono, dan Suhardi. 2007. Prosedur Analisa untuk Bahan Makanan dan Pertanian. Liberty, Yogyakarta.

Suriasih, K., W. R. Aryanta, G. Mahardika, and N. M. Astawa. 2012. Microbiological and chemical properties of kefir made of Bali cattle milk. FSQM 6: 12-22.
Temiz, H. and G. Kezer. 2015. Effects of fat replacers on physicochemical, microbial and sensorial properties of kefir made using mixture of cow and goat's milk. J. Food. Process. 39: 14211430.

Usmiati, S. dan A. Sudono. 2004. Pengaruh starter kombinasi bakteri dan khamir terhadap sifat fisikokimia dan sensori kefir. Jurnal Pascapanen 1: 12-21. 